\title{
Frequency and duration of the stages of the cycle of the seminiferous epithelium of the nine-banded armadillo (Dasypus novemcinctus)
}

\author{
C. N. Torres, H. P. Godinho and B. P. Setchell* \\ Departamento de Morfologia, Instituto de Ciencias Biologicas, UFMG, 30000 Belo Horizonte, \\ Brasil, and *A.R.C. Institute of Animal Physiology, Babraham, Cambridge CB2 4AT, U.K.
}

\begin{abstract}
Summary. The majority of the cross-sections of seminiferous tubules of nine-banded armadillos show only one type of cellular association as in most eutherian and metatherian mammals with scrotal testes. The spermatogenic cycle was divided into 8 stages, in relation to the shedding of the spermatozoa. The relative frequencies (\%) of stages 1-8 were, respectively: $16 \cdot 6,7 \cdot 5,12.9,9 \cdot 1,9 \cdot 7,18 \cdot 8,11.7$ and 13.6 . The duration of the cycle was 8.15 days, as determined by intratesticular injection of $\left[{ }^{3} \mathrm{H}\right]$ thymidine and removing the tissue at different times after injection.
\end{abstract}

\section{Introduction}

Nine-banded armadillos (Dasypus novemcinctus) have wide geographic distribution in the Americas, ranging from northern Argentina to central areas of the United States (Walker, 1968). Although they show several interesting features, including permanent abdominal testes, the reproductive biology of the males of this species has been little studied. Probably because they show delayed implantation of the blastocyst and polyembryony, their female reproductive cycle has been studied in greater detail (Newman, 1913; Hamlett, 1932; Talmage \& Buchanan, 1954; Enders, 1966; Peppler \& Canale, 1980). In a preliminary report, Godinho, Cardoso, Coser, Machado \& Nogueira (1977) have suggested that sexual activity of the male nine-banded armadillo may be seasonal since it exhibits annual variation in the weights of the testes and accessory genital glands as well as in the content of fructose and citric acid of the seminal vesicles, but Czekala, Hodges, Gause \& Lasley (1980) measured plasma testosterone concentrations and considered that testicular function continues throughout the year.

In the present paper, we present information on the relative frequency and duration of the stages of the cycle of the seminiferous epithelium of this animal. Weaker (1977) has already published a description of the cell associations found in the seminiferous tubules of this species, using a different system of classification but he makes no mention of the timing of the various stages or of the whole cycle.

\section{Materials and Methods}

Adult male armadillos weighing $4.1 \pm 0.5 \mathrm{~kg}$ were captured near Belo Horizonte $\left(19^{\circ} 49^{\prime} \mathrm{S}\right.$ and $43^{\circ} 56^{\prime} \mathrm{W}$ ) Brazil, between November and January, which is the period of the year of maximal testis weight (Godinho et al., 1977). The animals were killed by a blow to the head. A blood sample was collected from the heart and fragments of testicular tissue for histological studies 
were fixed for $6 \mathrm{~h}$ in Susa fixative (Lillie, 1954). The blocks were embedded in paraffin wax and cut at $10 \mu \mathrm{m}$. The sections were stained with haematoxylin and eosin.

The spermatogenic cycle was divided into 8 stages following criteria adopted by Curtis (1918), Roosen-Runge \& Giesel (1950), Swierstra (1968), Courot, Hochereau-de Reviers \& Ortavant (1970), Swierstra, Gebauer \& Pickett (1974) and Berndtson (1977). This system is based on the overall cell associations formed in cross-sections of the tubule, unlike the system of Clermont (1972) which is based on changes in acrosome morphology; Weaker (1977), in the only published study on armadillo spermatogenesis, used the Clermont system. In the present study, the relative frequencies of the stages were established by classifying, in 10 animals, a total of 4764 cross-sections of seminiferous tubules. The cross-sections counted were at least $600 \mu \mathrm{m}$ apart from each other.

To determine the duration of the spermatogenic cycle, testes of 5 animals were injected with approximately $100 \mu \mathrm{Ci}\left[{ }^{3} \mathrm{H}\right]$ thymidine (sp. act. $23 \mathrm{Ci} / \mathrm{mmol}$ : Radiochemical Centre, Amersham, U.K.) dissolved in $0.1 \mathrm{ml}$ of sterile water. The animals were anaesthetized with halothane and the injections were made into the testes either through the relaxed lateral abdominal wall, or directly through a median incision. The testes were removed under anaesthesia, or immediately after killing the animal at different times after injection: $1 \mathrm{~h}$ ( 3 testes), 7 days ( 2 testes), 10 days $17 \mathrm{~h}$ ( 2 testes) and 18 days $1 \mathrm{~h}$ ( 1 testis). They were fixed in Bouin's solution, embedded in paraffin wax and the $10 \mu \mathrm{m}$ sections coated with NTB-2 Kodak emulsion. The slides were exposed for 3-4 weeks, developed and finally stained with haematoxylin-eosin. Estimates of the duration of the cycle were made by recording the most advanced labelled germ cells at each time after the tracer injection (Clermont, 1972; Swierstra et al., 1974).

\section{Results}

\section{Stages of the cycle of the seminiferous epithelium}

Most cross-sections of seminiferous tubules presented cellular associations at only one stage of the cycle. The main features of each stage were as follows.

Stage 1 (Pl. 1, Fig. 1). Two types of A spermatogonia were observed. Type $\mathrm{A}_{1}$ had an ovoid nucleus with finely granular chromatin. The nuclear membrane showed deep indentations, producing an irregular outline. Type $\mathrm{A}_{2}$ had the same morphological appearance except that the

\section{PLATES 1 AND 2}

Partial cross-sections of armadillo seminiferous tubules; $10 \mu \mathrm{m}$ paraffin wax sections; $\mathrm{H} \& \mathrm{E}$ stain; Figs $1-7, \times 1140$; Figs 8 and $9, \times 1260$. $A_{1}=$ type $A_{1}$ spermatogonium; $A_{2}=$ type $A_{2}$ spermatogonium; In = intermediate type spermatogonium; $B=$ type $B$ spermatogonium; $\mathrm{PL}=$ preleptotene primary spermatocyte; $\mathrm{Z}=$ zygotene primary spermatocyte; $\mathrm{P}=$ pachytene primary spermatocyte; $\mathrm{S}=$ secondary spermatocyte; $\mathrm{M}=$ secondary spermatocyte undergoing division; $\mathrm{R}=$ round spermatid; $\mathrm{E}=$ elongated spermatid; $\mathrm{SE}=$ Sertoli cell. The letters refer to the nuclei vertically just below.

Figs 1-3. Stages 1 to 3 of the cycle, respectively.

Fig. 4. Stage 4 (upper half) and stage 5 (lower half) of the cycle.

Fig. 5. Stage 6 of the cycle, with a portion of a tubule (upper left corner) showing a typical intermediate spermatogonium.

Figs 6-7. Stages 7 and 8 of the cycle, respectively.

Figs 8 and 9. Autoradiographs obtained after intratesticular injection of $\left[{ }^{3} \mathrm{H}\right]$ thymidine showing grains on leptotene primary spermatocytes at stage 1 of the cycle, $1 \mathrm{~h}$ after injection (Fig. 8) and on elongated spermatids in stage 3, two cycles later than in Fig. 8, 18.04 days after injection (Fig. 9). 
PLATE 1

$4+20=0 \%+2$

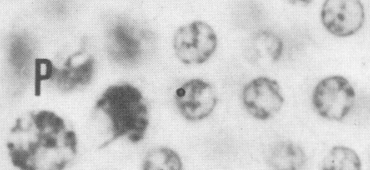
2. 3.90

$P L=09$

De 2 है 000

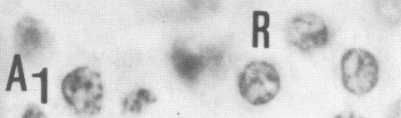

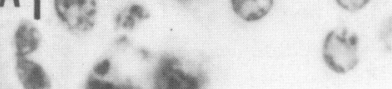

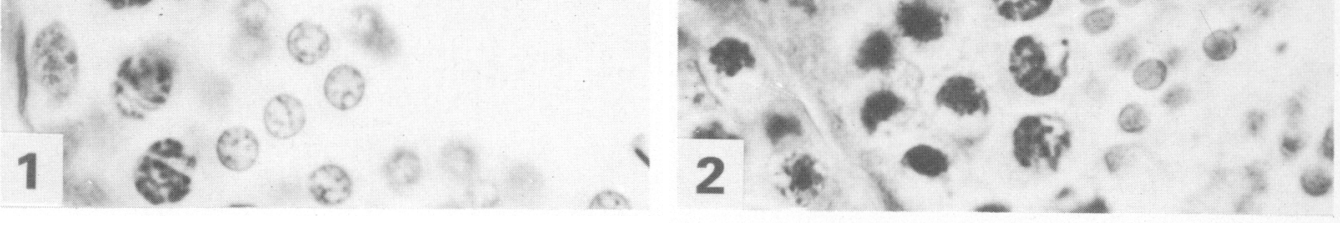

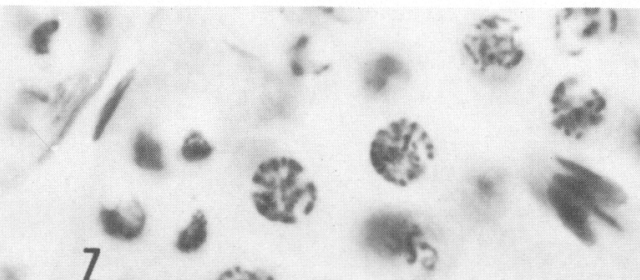

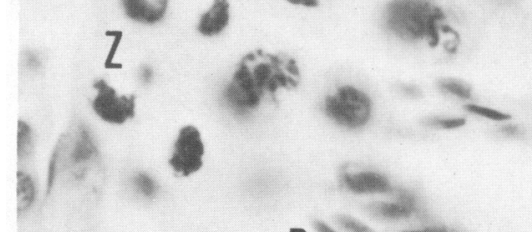

$48 y^{3}$ \& 4

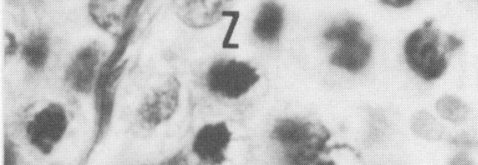
$u^{2} \operatorname{lig}^{2} x^{2}=0$ $\rightarrow+2=8^{\circ}$ $-106 x^{2}=0$ It

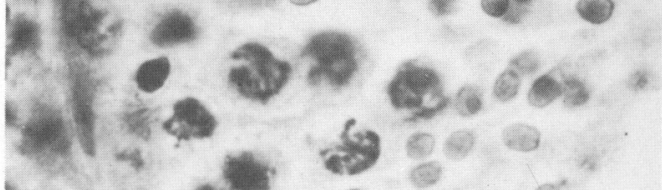

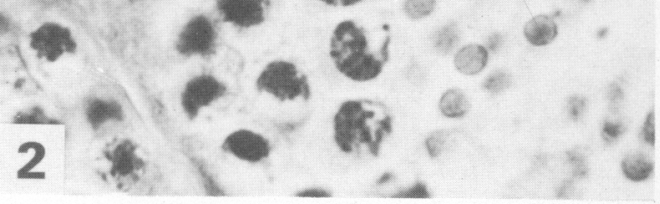

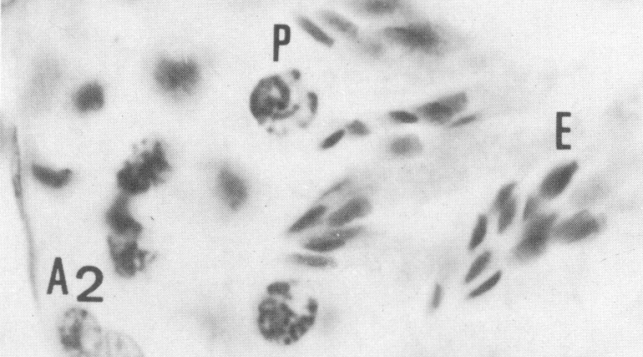
a. 6,1 3 $\rightarrow \rightarrow$ 
PLATE 2

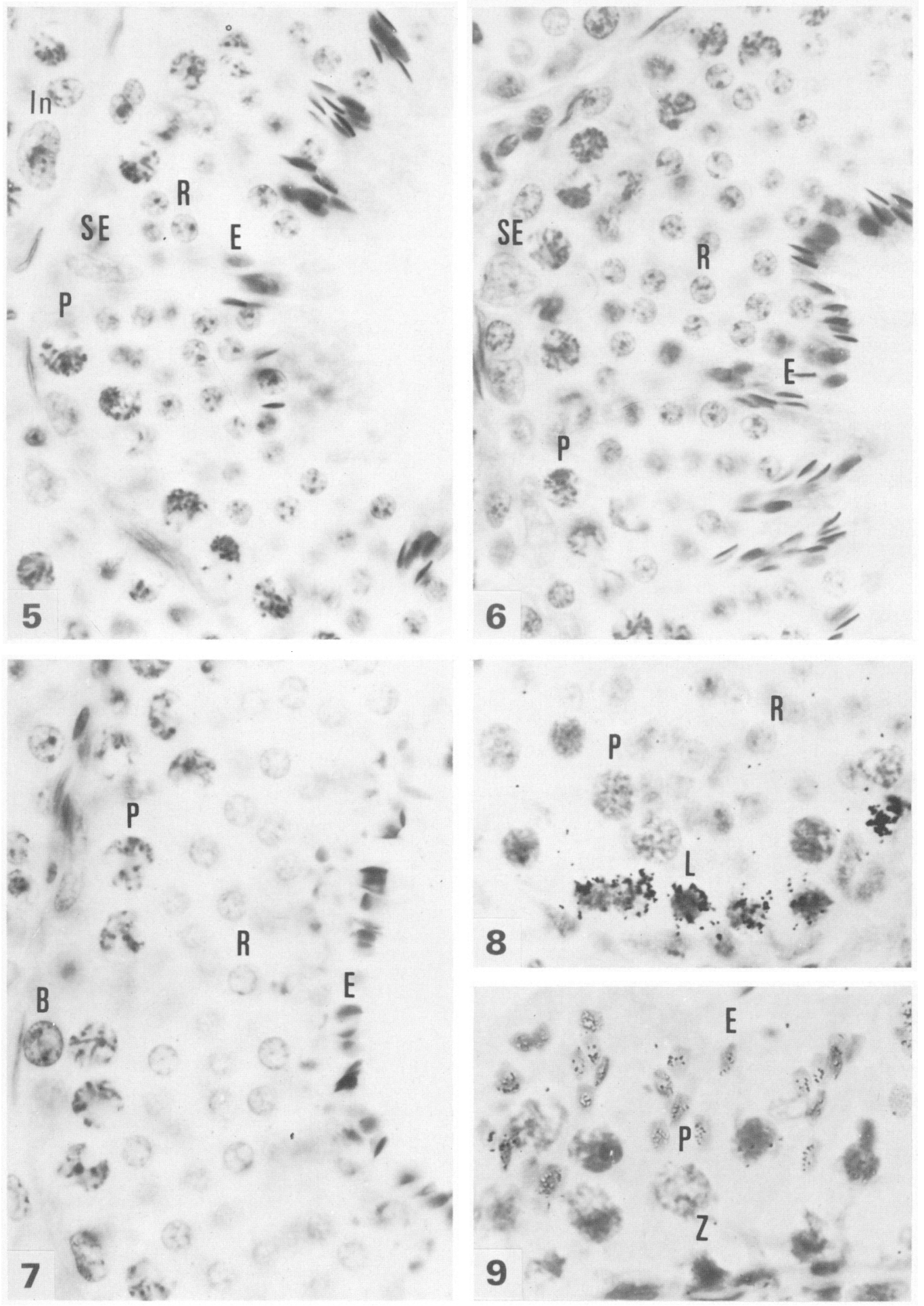


nuclear indentations were less pronounced. Both cell types were present in all stages of the cycle and were situated close to the basal membrane amongst Sertoli cells. Some type B spermatogonia were still present at the start of stage 1 . They had round or slightly elongated nuclei and coarse chromatin granules free in the nucleoplasm as well as adhering to the nuclear membrane. Primary spermatocytes were in preleptotene, reaching leptotene towards the end of the stage. An older generation of pachytene primary spermatocytes was present, organized in 1-3 cell layers. Round spermatids surrounded the lumen of the seminiferous tubules.

Stage 2 (Pl. 1, Fig. 2). Spermatids with elongating nuclei characterized this stage. The two generations of primary spermatocytes were still present, the younger generation being in leptotene and zygotene and the older still in pachytene.

Stage 3 (Pl. 1, Fig. 3). Spermatogonia of intermediate (In) type appeared at this stage. They had ovoid nuclei without indentations, the chromatin was arranged in coarse granules and, usually, they had two nucleoli (Pl. 2, Fig. 5). The young primary spermatocytes were in zygotene and the old ones in pachytene and diplotene. Elongated spermatids were arranged in bundles deeply embedded in the seminiferous epithelium.

Stage 4 (Pl. 1, Fig. 4). The character of the spermatocytes changed at this stage as old primary spermatocytes underwent meiotic division to give rise to secondary spermatocytes which had round nuclei containing granular chromatin and a nucleolus. The life-span of secondary spermatocytes seemed to be very short because there was a low relative frequency of stage 4. Anaphase and metaphase configurations of dividing primary and secondary spermatocytes were frequently observed in stage 4 . Intermediate spermatogonia seemed to have increased in number at this time.

Stage 5 (Pl. 1, Fig. 4). $\mathrm{A}_{1}, \mathrm{~A}_{2}$ and In types of spermatogonia lined the tubular wall and showed the same morphological features as those seen in earlier stages. The only generation of primary spermatocytes present at this stage was in zygotene. The newly formed spermatids showed round nuclei with granules of chromatin connected by chromatin filaments. The bundles of elongated spermatids remained deeply embedded in the seminiferous epithelium close to the nuclei of the Sertoli cells.

Stage 6 (Pl. 2, Fig. 5). Intermediate spermatogonia continued to increase in number and towards the end of the stage they had started to divide into B spermatogonia. The primary spermatocytes were in pachytene. The round nuclei of the spermatids contained a clear nucleoplasm in which 2 or 3 large granules were seen. The bundles of elongated spermatids lay in the middle of the seminiferous epithelium.

Stage 7 (Pl. 2, Fig. 6). No intermediate spermatogonia were seen from here to stage 3 of the following cycle but there was an increase in the numbers of type B spermatogonia which appeared to divide into preleptotene primary spermatocytes at the end of this stage. Two generations of primary spermatocytes were therefore apparently present from the end of stage 7 to the next stage 4 . The old primary spermatocytes, in pachytene, and round spermatids had the same disposition as in stage 6. Displacement of bundles of elongated spermatids towards the lumen was the main characteristic of the stage.

Stage 8 (Pl. 2, Fig. 7). Cells which appeared to be young primary spermatocytes in preleptotene were interspersed among the $A_{1}$ and $A_{2}$ spermatogonia and the Sertoli cells but there were also some type $B$ spermatogonia remaining. The older generation of primary spermatocytes remained in pachytene. Round spermatids still had the same characteristics as those found in stages 6 and 7. The elongated spermatids lined the lumen of the seminiferous tubules ready to be released.

\section{Frequency of the stages of the cycle}

The relative frequency, expressed in percentages, for each stage of the cycle is shown in Table 1. The pre-meiotic part of the cycle (stages 1-3) corresponded to $37 \%$ of one cycle and 
contained a single generation of spermatids. The old primary spermatocytes attained their final development during this part of the cycle to give rise to secondary spermatocytes at stage 4 . The post-meiotic part of the cycle (stages 5-8) included two generations of spermatids and corresponded to $57 \%$ of the cycle. Stages $2(7 \cdot 5 \pm 1.4 \%)$ and $6(18.8 \pm 2 \cdot 7 \%)$ were the shortest and the longest of the cycle, respectively.

Table 1. Frequency (mean \pm s.d.) and duration of each stage of the spermatogenic cycle in armadillos $(\mathrm{N}=10)$

\begin{tabular}{lccccccccc}
\hline & \multicolumn{1}{c}{ Stage } \\
\cline { 2 - 9 } & 1 & 2 & 3 & 4 & 5 & 6 & 7 & 8 \\
\hline Frequency (\%) & 16.6 & 7.5 & 12.9 & 9.1 & 9.7 & 18.8 & 11.7 & 13.6 \\
Duration (days) & \pm 2.6 & \pm 1.4 & \pm 3.0 & \pm 1.5 & \pm 1.4 & \pm 2.7 & \pm 2.5 & \pm 2.8 \\
\hline
\end{tabular}

\section{Duration of the cycle}

Leptotene primary spermatocytes at stage 2 of Cycle II were the most advanced labelled germinal cells $1 \mathrm{~h}$ after intratesticular injections of $\left[{ }^{3} \mathrm{H}\right]$ thymidine (PI. 2, Fig. 8). On Day 7 after injection, the label had progressed to pachytene primary spermatocytes at stage 8 of Cycle II, having passed through 0.84 of a cycle. On Day 10.7 , the label had reached secondary spermatocytes in stage 4 of Cycle III and on Day 18.07 it reached elongated spermatids at the beginning of stage 3 of Cycle IV (Pl. 2, Fig. 9). The mean duration of one cycle (Table 2) was calculated to be $8.15 \pm 0.1$ (s.e.m.) days. The life span, in days, of the germinal cells was: primary spermatocytes 12.2 days; secondary spermatocytes 0.7 days; round spermatids 5.7 days; and elongated spermatids 6.8 days.

Table 2. Estimates of the duration of one cycle of the seminiferous epithelium in the armadillo

\begin{tabular}{|c|c|c|c|c|c|c|}
\hline \multirow[b]{2}{*}{$\begin{array}{c}\text { Time after } \\
\text { injection of } \\
{\left[{ }^{3} \mathrm{H}\right] \text { thymidine }}\end{array}$} & \multicolumn{2}{|c|}{ Most advanced labelled cell } & \multicolumn{2}{|c|}{$\begin{array}{c}\text { Interval since } \\
\text { labelling leptotene } \\
\text { primary spermatocytes }\end{array}$} & \multicolumn{2}{|c|}{$\begin{array}{c}\text { Duration of one cycle } \\
\text { (days) }\end{array}$} \\
\hline & Cell type & $\begin{array}{l}\text { Cycle } \\
\text { and } \\
\text { stage }\end{array}$ & $\begin{array}{c}\text { No. of } \\
\text { cycles } \\
\text { traversed }\end{array}$ & $\begin{array}{l}\text { Time } \\
\text { (days) }\end{array}$ & $\begin{array}{l}\text { Based on the } \\
\text { initial point } \\
\text { of labelling }\end{array}$ & $\begin{array}{l}\text { Based on } \\
\text { intermediate } \\
\text { points of } \\
\text { labelling }\end{array}$ \\
\hline 1 hour & $\begin{array}{l}\text { Primary spermatocyte } \\
\text { (leptotene) }\end{array}$ & II, 2 & - & - & - & - \\
\hline 7 days & $\begin{array}{l}\text { Primary spermatocyte } \\
\text { (pachytene) }\end{array}$ & II, 8 & 0.84 & 6.95 & $8 \cdot 27$ & - \\
\hline 10.7 days & Secondary spermatocyte & III, 4 & $1 \cdot 3$ & $10 \cdot 6$ & $8 \cdot 15$ & $8 \cdot 04^{*}$ \\
\hline 18.04 days & Elongated spermatid & IV, 3 & $2 \cdot 2$ & $18 \cdot 0$ & $8 \cdot 18$ & $8 \cdot 15 \dagger$ \\
\hline
\end{tabular}

* Based on difference in labelling pattern 10.7 and 7 days after injection.

$\dagger$ Based on difference in labelling pattern 18.04 and 10.7 days after injection.

\section{Discussion}

The seminiferous epithelium of the non-scrotal armadillo testis is organized into cellular associations of mixed composition and most cross-sections of its seminiferous tubules show only one type of cellular association, as is found in most eutherian and metatherian mammals with scrotal testes. Therefore, the spermatogenic cycle of the armadillo may also be divided into 8 stages by the method of "tubular morphology" (Berndtson, 1977) which relies upon the morphology of the nuclei of the spermatids, their position and arrangement in the seminiferous 
epithelium, the presence of secondary spermatocytes and the liberation of spermatozoa into the lumen of the tubule (Curtis, 1918; Roosen-Runge \& Giesel, 1950; Courot et al., 1970; Swierstra et al., 1974).

The only other paper on the cycle of the seminiferous epithelium of armadillos is that of Weaker (1977) who employed the alternative method based on spermatid development (Clermont, 1972) to divide the cycle into 10 stages. Comparison of the two methods reveals a general agreement regarding the cellular composition of the stages, except on the location of type B spermatogonia and preleptotene primary spermatocytes in the cycle. The data of Weaker (1977), when adapted to the method of tubular morphology, indicate B spermatogonia only in stages 8 and 1 , and preleptotene in stage 2 of the cycle. In our material, B spermatogonia were seen from the end of stage 6 to stage 1 of the next cycle but they appeared to begin dividing into preleptotene primary spermatocytes from stage 7 . The divisions of the B spermatogonia may therefore be less completely synchronized with other events in the seminiferous epithelial cycle in the armadillo than in other species, or alternatively there may be two generations of $B$ spermatogonia as in the bull and ram (Courot et al., 1970), with the second generation appearing very like preleptotene spermatocytes.

The relative frequencies of the stages and the duration of the cycle are described in the armadillo for the first time. As in the rat (Roosen-Runge \& Giesel, 1950; Hochereau, 1963a, b) and pig (Swierstra, 1968) stage 6 is the most frequent, while stage 2 is the least frequent. The pre-meiotic part of the cycle is considerably shorter than the post-meiotic part, the proportion being very similar to that of the mink (Tiba, Ishikawa \& Murakami, 1968), dog (Foote, Swierstra \& Hunt, 1972), tammar wallaby (Setchell \& Carrick, 1973) and horse (Swierstra et al., 1974). The different estimates made to calculate the duration of the cycle ( $8 \cdot 15$ days) gave similar results, indicating that the progression of the label was correctly demonstrated (Swierstra, 1968). In a few mammals so far studied, the duration of the cycle ranges from 6.7 days in the bank vole (Grocock \& Clarke, 1976) to 17.7 days in the Bennett's wallaby (Setchell \& Carrick, 1973). The cycle in armadillos is therefore amongst those of short duration. Because it is impossible to determine the beginning of the spermatogenic process, it is assumed that it extends approximately over 4 consecutive cycles (Courot et al., 1970). Based on this assumption the whole spermatogenic process of armadillos would last 32.6 days.

The nuclear indentation of type A spermatogonia, previously described by Weaker (1977), seems to be a morphological characteristic of the armadillo testis since it has been described only for this species. Nagy \& Edmonds (1973) did not refer to this nuclear indentation in their study of armadillo spermatogonia although it is clearly illustrated in their paper. The morphology of the other germinal cells of the armadillo is very similar to that of other mammals with scrotal testis.

We thank Mrs R. R. Chagas for technical assistance and the Brazilian "Conselho de Desenvolvimento Cientifico e Tecnologico (CNPq)" for supporting this research.

\section{References}

Berndtson, W.E. (1977) Methods for quantifying mammalian spermatogenesis: a review. J. Anim. Sci. 44, 818-833.

Clermont, Y. (1972) Kinetics of spermatogenesis in mammals: seminiferous epithelium cycle and spermatogonial renewal. Physiol. Rev. 52, 198-236.

Courot, M., Hochereau-de Reviers, M.T. \& Ortavant, R. (1970) Spermatogenesis. In The Testis, Vol. 1, pp. 339-432. Eds A. D. Johnson, W. R. Gomes \& N. L. VanDemark. Academic Press, New York.

Curtis, G.M. (1918) The morphology of the mammalian seminiferous tubule. Am. J. Anat. 24, 339-394.
Czekala, N.M., Hodges, J.K., Gause, G.E. \& Lasley, B.L. (1980) Annual circulating testosterone levels in captive and free-ranging male armadillos (Dasypus novemcinctus). J. Reprod. Fert. 59, 199-204.

Enders, A.C. (1966) Reproductive cycle of nine-banded armadillo (Dasypus novemcinctus). Symp. zool. Soc. Lond. 15, 295-310.

Foote, R.H., Swierstra, E.E. \& Hunt, W.L. (1972) Spermatogenesis in the dog. Anat. Rec. 173, 341352.

Godinho, H.P., Cardoso, F.M., Coser, A.M.L., Machado, A.B.M. \& Nogueira, J.C. (1977) Biologia 
reproductiva de machos Dasypus novemcinctus. Cienc. Cult. 29, Abstr. 793.

Grocock, C.A. \& Clarke, J.R. (1976) Duration of spermatogenesis in the vole (Microtus agrestis) and bank vole (Clethrionomys glareolus). J. Reprod. Fert. 47, 133-135.

Hamlett, G.W.D. (1932) The reproductive cycle in the armadillo. Z. Wiss. Zool. 141, 143-157.

Hochereau, M.T. (1963a) Etude comparée de la vague spermatogénétique chez le taureau et chez le rat. Annls Biol. anim. Biochim. Biophys. 3, 5-20.

Hochereau, M.T. (1963b) Constance des frequences relatives des stades du cycle de l'epithelium seminifère chez le taureau et chez le rat. Annls Biol. anim. Biochim. Biophys. 3, 93-102.

Lillie, R.D. (1954) Histopathologic Technic and Practical Histochemistry. Blakiston Co., New York.

Nagy, F. \& Edmonds, R.H. (1973) Morphology of the reproductive system of the armadillo. The spermatogonia. J. Morph. 140, 307-319.

Newman, H.H. (1913) The natural history of the nine-banded armadillo of Texas. Am. Nat. 47, 513-539.

Peppler, R.D. \& Canale, J. (1980) Quantitative investigation of the annual pattern of follicular development in the nine-banded armadillo (Dasypus novemcinctus). J. Reprod. Fert. 59, 193-197.

Roosen-Runge, E.C. \& Giesel, L.O. (1950) Quantitative studies on spermatogenesis in the albino rat. $A m . J$. Anat. 87, 1-23.

Setchell, B.P. \& Carrick, F.N. (1973) Spermatogenesis in some Australian marsupials. Aust. J. Zool. 21, 491-499.

Swierstra, E.E. (1968) Cytology and duration of the cycle of the seminiferous epithelium of the boar; duration of spermatozoan transit through the epididymis. Anat. Rec. 161, 171-186.

Swierstra, E.E., Gebauer, M.R. \& Pickett, B.W. (1974) Reproductive physiology of the stallion. I. Spermatogenesis and testis composition. J. Reprod. Fert. 40, 113-123.

Talmage, R.V. \& Buchanan, G.D. (1954) The armadillo (Dasypus novemcinctus) A review of its natural history, ecology, anatomy and reproductive physiology. Rice Inst. Pamphlet 41, 1-135.

Tiba, T., Ishikawa, T. \& Murakami, A. (1968) Histologische Untersuchung der Kinetik der Spermatogenese beim Mink (Mustela vison). I. Samenepithelzyklus in der Paarungszeit. Jap. J. vet. Res. 16, 73-85.

Walker, E.P. (1968) Mammals of the World, Vol. 1, p. 482. Johns Hopkins Press, Baltimore.

Weaker, F.J. (1977) Spermatogonia and the cycle of the seminiferous epithelium in the nine-banded armadillo. Cell Tiss. Res. 179, 97-109.

Received 24 April 1980 